\title{
アルミニウム青銅の腐食現象*
}

椙 山正孝** 小林啓佑**

\section{On the Corrosion of Aluminum Bronze}

Masataka Sugiyama and Keisuke Kobayashi

Corrosion of binary $\mathrm{Cu}-\mathrm{Al}$ alloys was investigated in sea water. Single phase specimens of $\alpha, \beta^{\prime}$ or $\gamma_{2}$ respectively were prepared and tested on corrosion loss, corrosion potential, polarization characteristics and cathodic protection.

The results were as follows:

1) In $\alpha$ phase, corrosion loss decreased as $\mathrm{Al}$ content increased.

2) In $\beta^{\prime}$ phase, corrosion loss was less than in $\alpha$ and $\gamma_{2}$ phases, and passivity was observed in the anodic polarization curves between 10 and $70 \mu \mathrm{A} /$ $\mathrm{cm}^{2}$.

3) In $\gamma_{2}$ phase, dealuminization and redeposit of $\mathrm{Cu}$ were observed.

4) The current density and the potential for cathodic protection of $\alpha$ phase castings were 10 $\mu \mathrm{A} / \mathrm{cm}^{2}$ and $-0.4 \mathrm{~V}$ (vs. S. C. E.).
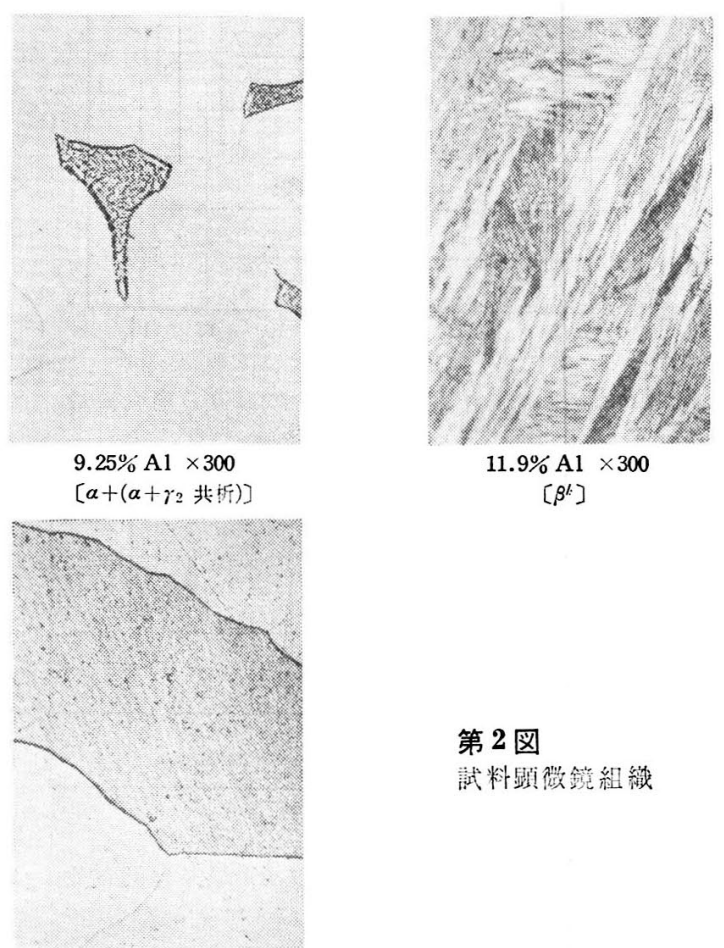

$16 \% \mathrm{Al} \times 200$

[r.

第 2 図

料料微鏡組緎
平:澛状態図である

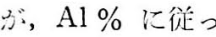
(Raynor ${ }^{1)}$ )

$\asymp \alpha, \beta, \gamma_{2}$ 之相変化し， $\beta$ 相は高温安定相で常温では 徐冷された場合は $\left(\alpha+\gamma_{2}\right)$ 共析組織，急冷された場合は 銓の martensite に似た $\beta^{\prime}$ なる相を形成寸る。实用合 全法 $\mathrm{Fe}, \mathrm{Ni}, \mathrm{Mn}$ 等を含むが大別して $\alpha$ 相，および $\left(\alpha+\beta^{\prime}\right)$ 相よりなるものが多く， $\gamma_{2}$ 相を含むものは脆性 を示すのでできる限り避けている。諸組織の顕微鏡写真 を第 2 図に示す。アルミニウム青銅の腐食や Zn による

* 昭和 34 年 11 月 25 日第 3 回防食技術研究討論会に発表

** 東京大学工学部冶金学教室（東京都交京区本富士町）

陰極防食について二, 三の報告2 5) があり他の銅合金に 比べて腐食減量が少なく耐腐食疲労, 耐キャビテーショ ンにすぐれ，黄銅の脱 $\mathrm{Zn}$ に相当する脱 $\mathrm{Al}$ 現象がわず かながら観察されることが知られている。ここでは各相 の海水中での挙動について自然電極電位, 腐食減量, 分 極特性，ガルバニック電流，陰㥛防食などについて行な 
防蝕技術

った二，三の絬果について報告する。

\section{2. 試料の調 整}

電解銅および高純度 $\mathrm{Al}$ をクリプトル炉にて溶解，石 高型に錼込み, 所要寸法に仕上げ, 熱処理を行ない, エ メリー04 まで研摩, エーテルで脱脂後 10２0 min 程 度で必要部分を残して他它パラフィンで被覆して使用し た。焼鈍条件は $850^{\circ} \mathrm{C} \times 1 \mathrm{hr}$ 焼鈍後 $520^{\circ} \mathrm{C}$ まで徐冷し $520^{\circ} \mathrm{C}$ で $4 \mathrm{hr}$ 保ち $\beta \rightarrow\left(\alpha+\gamma_{2}\right)$ 变態を完全に行ない, また焼入条件注 $900^{\circ} \mathrm{C} \times 2 \mathrm{hr}$ 加熱後水焼入れとした。 腐食液としての海水は JIS K 5631 に定める人工海水を 使用した。

\section{3. 実験方法および結果}

\section{$3 \cdot 1$ 海水中における腐食減量および自然電極電位}

試料 $\left(5 \times 5 \times 5 \mathrm{~mm}^{3}\right)$ を上湍の水深 $5 \sim 10 \mathrm{~mm}$ に浸漬 乙，自然電㥛電位の洔间的变化を测定した。同時に $5 \times$

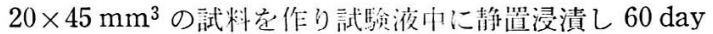
後, 電位および腐食減量を测定した。電位测定は飽和甘 湬電極を照合電極とし東洋理化 KK K製真空管電位差計を

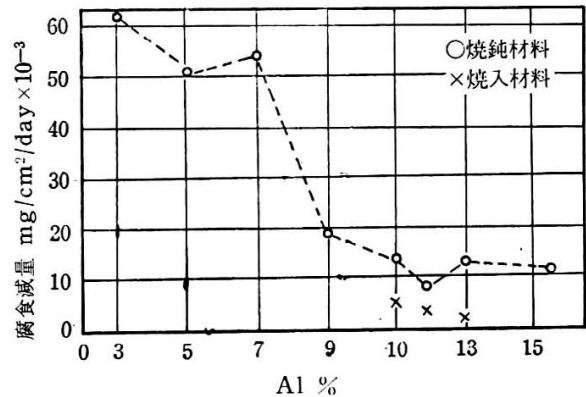

第 3 図 $\mathrm{Cu}-\mathrm{A} 1$ 合金の海水中における腐食減量 (60 day 浸湑)

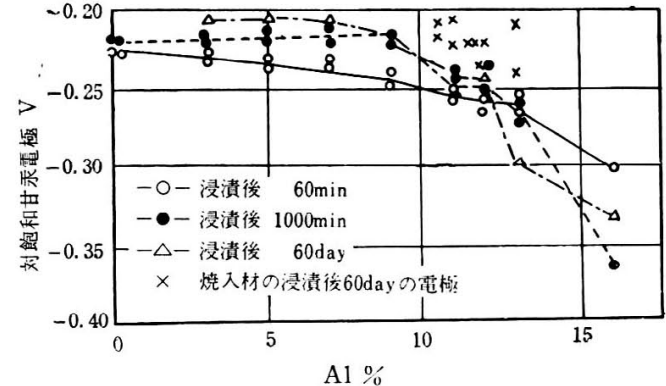

第 4 図 $\mathrm{Cu}-\mathrm{A} 1$ 合金の海水中における自然電位

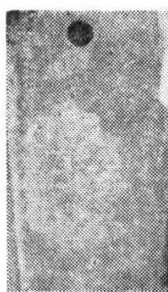

$7 \% \mathrm{Al}$

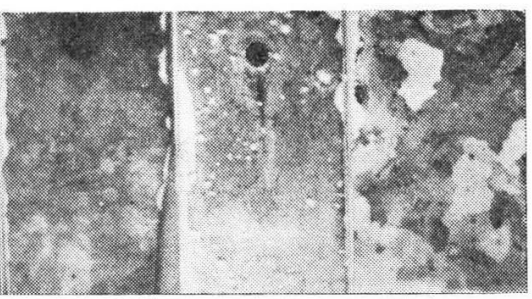

$11.9 \% \mathrm{Al}\left(\beta^{\prime}\right) \quad 11.9 \% \mathrm{Al}\left(\alpha+\gamma_{2}\right) \quad 16 \% \mathrm{AI}\left(\gamma_{2}\right)$ 第 5 図腐食試験片外観写真 (人工海水中 60 day 静漼浸清後)

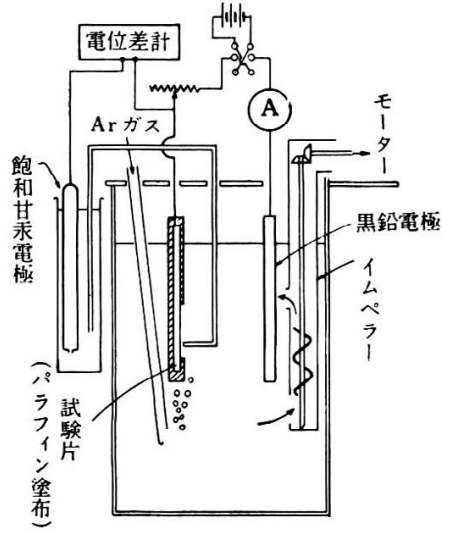

第 6 図定電流法分極測定装置

使用した。実験結 果は第 3〜5 図に 示吉。

$3 \cdot 2$ アルミニ ウム青銅金属組 織中の各相の分 壻特性

Al $7 \%(\alpha$ 相), Al $11.9 \%$ (焼入れ によって $\beta^{\prime}$ 単相 としたもの), $\mathrm{Al}$ $16 \%\left(\gamma_{2}\right.$ 相) の行 組織について第 6 図のごとく試験片 を設置し，試験衣面稓を $30 \times 30 \mathrm{~mm}^{2}$ とし，定電流洪

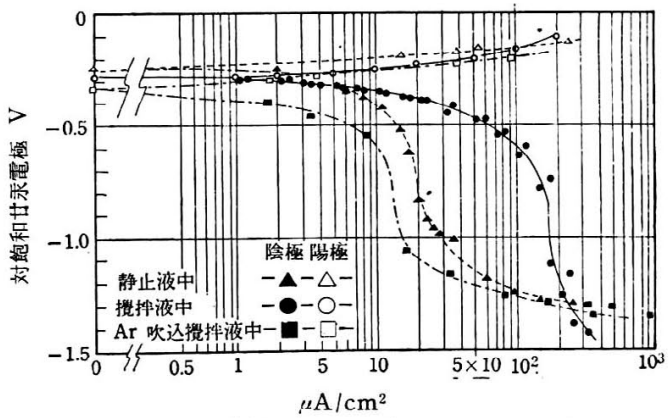

第 7 図 $\mathrm{Al} 7 \%(\alpha$ 相) 合金分極曲線

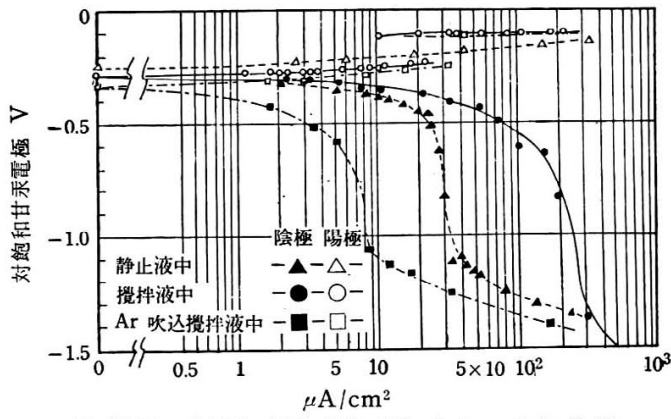

第 8 図 Al 11.9\%（ $\beta^{\prime}$ 相）合金の分極曲線

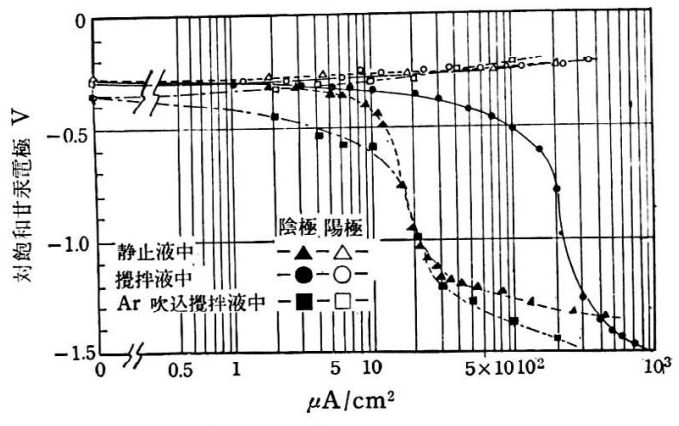

第 9 図 Al 16\%（ $\gamma_{2}$ 相）合金の分極曲線 
によって分 惯曲線を作

製した。掜 排条件はイ ソペラーに よって空気 の飽和状態 で行ない,

Ar ガス吹 远みは試䮖 液を煮沸後 Ar ガス萑 通じながら 肦却, 続け てAr ガス を吹込みな がら行なっ た。実駼温 废汁 $25^{\circ} \mathrm{C}$ に塥節し，

得られた䋊 果的第 7 9 図儿示 す。

$3.3(\alpha-$ $\left.\boldsymbol{r}_{2}\right)$ 対の カルバニ ック電流

種々の面 積の $\alpha-\gamma_{2}$ 対を両極間 隔 $40 \mathrm{~mm}$ として両極 闬を $2 \Omega$ の 抓抗で絬び 㭘流計を並 列に入れて 柃流計飞流 丸る電流を 白仁させて $3 \sim 4 \mathrm{hr}$ で 添淁安定電 流汇達した 们妾読えだ。静止液, および鄮拌液中における結果を第 10 图に示与。

\section{$3.47 \% \mathrm{Al}$ 青銅鋳物の陰極防食}

$\alpha$ 相鋳物 $\left(3 \times 40 \times 40 \mathrm{~mm}^{3}\right)$ について㓌極電流密度一腐
食減量の関係を求めた結果は第 11 図に示す通りである。

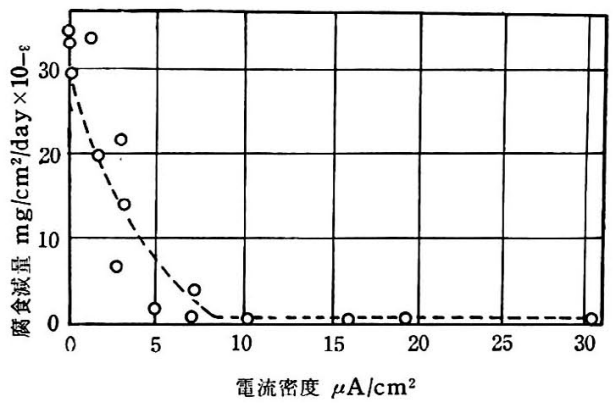

第 11 図 $\alpha$ 単相フルミニウム青銅鋳物（A1 7\%） の陰極電流之腐食減量の変化 (静止海水中 12 19 day)

\section{4. 結果の考察}

腐食減量は $\mathrm{A} 1$ の高くなるに従って減少の傾向が見ら れる。9.6\% Al 以上の焼鈍試料は二相合金であるが (一 般には非平衡組織のため更に低 $\mathrm{Al}$ でも $\gamma_{2}$ は現われる) 試料を焼入れて単相組織としたものでは高 $\mathrm{Al}$ が減量の 少ない傾向がある。

$\alpha$ または $\beta^{\prime}$ 単相よりなるものとは異なり, $\left(\alpha+\gamma_{2}\right)$ 共 析よりなる合金では局部陽極となる $\gamma_{2}$ の選択腐食が淮 行し， $\gamma_{2}$ の部分に孔食が生じ, $\mathrm{Al}(\mathrm{OH})_{3}$ と思われる白 色腐食生成物を生じ，その下は銅色を呈し明らかに脱 Al 現象を起している。

$\gamma_{2}$ 単相の場合も銅色表面を示すが試料表面の X 線回 折の結果および表面組織から明らかなように $\mathrm{Cu}$ の再析 出と考えられる（第 12 図）。

腐食電位については浸漬初期は $\mathrm{Al} \%$ によって $\propto$ 相

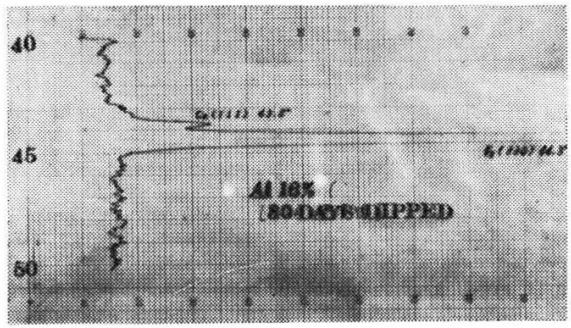

$\mathrm{u} \rightarrow$

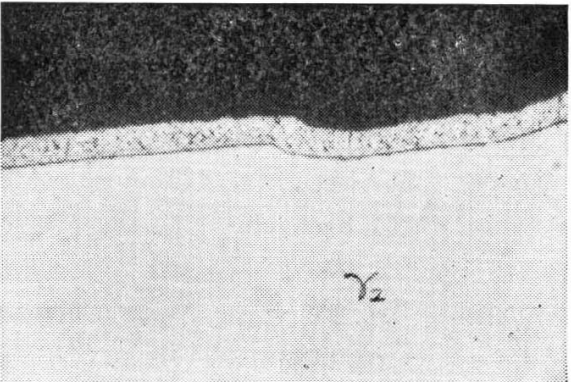

第 12 図 $\gamma_{2}$ 相の脱 $\mathrm{A} 1$ 表面の $\mathrm{X}$ 線回折 結果および顕微鏡写真 $(\times 600)$ 
でも Al 量の増加に伴い less noble になる傾向が見ら れ,一般に $\alpha, \beta^{\prime}, \gamma_{2}$ の順に less noble になるが長期腐 食後注 $\alpha$ 相はほぼ同一電位に， $\beta^{\prime}$ もほぼ同一電位を示 すが， $\gamma_{2}$ 相は著しく less noble な优を示す。長期浸漬 によっていくぶん noble になるのは redeposit した $\mathrm{Cu}$ により表面が覆われるためである。なお $\gamma_{2}$ の海水中で 破断直後の破断面の電位の瞬間読みは $-0.6 \sim-0.7 \mathrm{~V}$ を示し，このことからむ】 $\gamma_{2}$ の供試材は表面酸化の著し いものであることがわかる。

分極曲線については攪拌液中の $\beta^{\prime}$ の陽分極に不働態 の形成が明瞭に見られる。静止液中において子第 8 図に 法されていないが $70 \mu \mathrm{A} / \mathrm{cm}^{2}$ で $15 \mathrm{hr}$ 放置した場合 には不働態化が見られた。 $\alpha, \gamma_{2}$ にこのような現象が $\beta^{\prime}$ ほど明瞭に見られなかったのは不働態の形成に $\mathrm{Al} \%$ が 重要な意味を持つもので $\alpha, \gamma_{2}$ の場合に比べて $\beta^{\prime}$ の場 合が合金成分や，結晶構造から最も強い酸化皮膜を作る むのが，または $\gamma_{2}$ の場合は試料調整中の酸化が後の現 象にまで影響を与えて不働態化を不明確なものにしてい るのではないかと考光られる。和 が noble でかつ腐食 減量が少なく, $\gamma_{2}$ が less noble で脱 Al を示すのも $\mathrm{Al} \%$ と酸化皮膜の関係を示すものと考兄られる。 $\beta^{\prime}$ 相 における陽極電流密度一電位一時間の関係を第 13 図に

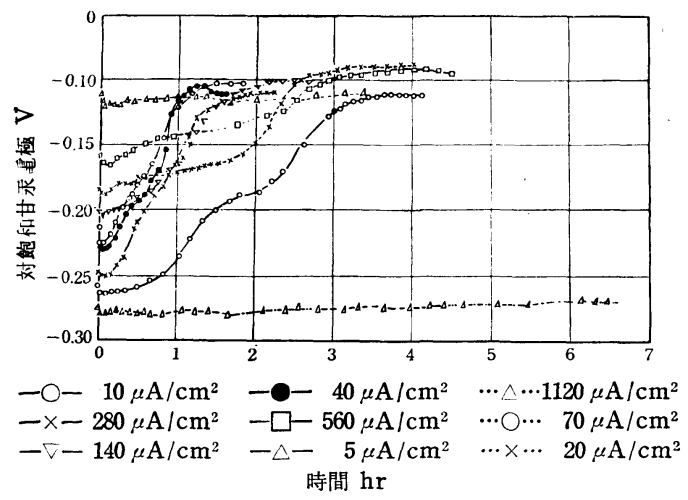

第13 図 $\beta^{\prime}$ 相の陽極電流密度一電位一時間曲線 (点線および破線は試料面の刻倉されたもの)

示すが電流密度 >約 $140 \mu \mathrm{A} / \mathrm{cm}^{2}$ およびく約 $5 \mu \mathrm{A} / \mathrm{cm}^{2}$ の場合法試料面の流出による食刻が起り, $10 \mu \mathrm{A} / \mathrm{cm}^{2} \sim$ $70 \mu \mathrm{A} / \mathrm{cm}^{2}$ では酸化による不㗢態の形成により部分的 な孔食を除いては食刻は全く見られない。不働態化した 場合の自然電位は $-0.23 \sim-0.20 \mathrm{~V}$ でこの值は攪找液 中では $\alpha$ 相のそれと同じ，もしくは more noble であ る。これら不働態に $8 \mu \mathrm{A} / \mathrm{cm}^{2}$ の陰極電流を通じると 容易に再び活性状態に還る。不働態の存在による陰分極 は $8 \mu \mathrm{A} / \mathrm{cm}^{2}$ で $\approx 0.2 \mathrm{~V}$ で活性状態の $0.01 \sim 0.03 \mathrm{~V}$ に比べると大きい（第 14 図）。

$\boldsymbol{\beta}^{\prime}$ 試料の $\mathrm{H}_{2} \mathrm{O}_{2}$ 処理によって表面に酸化皮膜を形成 させたものもほとえど同じ電気化学的挙動を示すことも

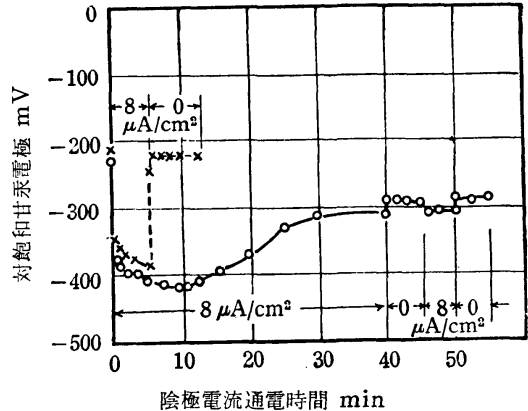

第 14 図不㗢態化した $\beta^{\prime}$ 相に陰極電流 $8 \mu \mathrm{A} / \mathrm{cm}^{2}$ を通した場合の電位 变化の傾向
確哂した。 次に $\alpha$ $r_{2}$ 対のガ ルハシニック 電流につい ては模型試 駼維果であ り,この絬 身放与多く を類推する ことは危険 でありまた 当を得ないことも確かである。酸化皮膜の生じた $\gamma_{2}$ は 浸漬初期は $\alpha$ に対し noble であるが 2 min 程度で less. noble になり 4〜 $5 \mathrm{hr}$ で一応変化の少ない電位（静止液 中で $-0.28 \mathrm{~V}$ ，攪找液中で $-0.31 \mathrm{~V})$ になるが，第 4 図の電位变化から見ても明らかなように開路電位は徐々 に less noble になる。実際に起る $\alpha-\gamma_{2}$ 間のガルバニ ック電流はこのような大きな電位差を持った対によって 起るものでこの場合 $\gamma_{2}$ の性質は本実験の範囲内のもの. とはかなり異なることは考虑する必要がある。

本実験については静止液中における場合は陰極面積の. 変化による影響の方が大きいが，䚌汼液中ではその傾向 は小さい。これは腐食が酸素消費によって進行し，㨨挷 しない場合は酸素不足のため陰分極が大きく陰極面積の 影響が大で，鄮汼の場合は酸素の供給が十分で, 液間抵 抗の方が大きく影響するため陰陽両極の面積变化が問題. になると考えられる。フルミニウム青銅の海水中におけ る腐食では $\beta^{\prime}$ は不働態の形成などで noble な電位に変 化乙易いのに比べて， $\gamma_{2}$ は局部陽極を形成し易く，実用 合金で $\gamma_{2}$ が析出する場合は粒界に微量存在することが 多いので粒界に腐食を生ずることになり， $\gamma_{2}$ の存在は 機械的性質の点ばかりでなく耐食性材料としても避けな ければならない。

静止海水中における陰極防食電流について から約 $10 \mu \mathrm{A} / \mathrm{cm}^{2}$ 以上で腐食隇量はなくなる。その際 の防食電位第 7 図の $\alpha$ 相陰分極曲線から約 $-0.4 \mathrm{~V}$ であることがわかる。 $\mathrm{Al}$ 合金については陰極電流によ る酸素還元のため $\mathrm{pH}$ が上昇し過防食現象の起ることが 報告されているが重量测定法による本実験で注 $30 \mu \mathrm{A} /$ $\mathrm{cm}^{2}$ まで注過防食は見られず， $30 \mu \mathrm{A} / \mathrm{cm}^{2}$ で法試料金 面に白色付着物が形成されたが，これは $\mathrm{CaCO}_{3}$ を主成 分とするもので $\mathrm{Mg}$ 塩などが含まれていた。

\section{5. 総括}

$\mathrm{Cu}-\mathrm{A} 1$ 二元合金の海水中における腐食現象として 次 のごとき結果が得られた。

11） A $\%$ が増加すると腐食減量は少なくなるが $\gamma_{2}$. 
相の存在する場合は局部陽極を形成し，孔食，脱 $\mathrm{Al}$ が 著しく材質劣化の原因となるので耐食性の点からも $\gamma_{2}$ の存在汢避けるのが望ましい。

（2） $\beta^{\prime}$ 相は 10 70 $\mu \mathrm{A} / \mathrm{cm}^{2}$ の陽極電流で容易に不働 態化し，不働態は他相の場合より安定していると考えら れる。

(3) $\alpha$ 単相の $\mathrm{Cu}-\mathrm{Al}$ 二元合金鋳物㤌電流密度 $10 \mu \mathrm{A}$ / $\mathrm{cm}^{2}$ ，電位 $-0.4 \mathrm{~V}$ (対飽和甘承電極) で㓌極防食を行
なうことができ，また $<30 \mu \mathrm{A} / \mathrm{cm}^{2}$ では過防食現象は 見られなかった。 （昭和 35 年 9 月 17 日受理）

\section{参 考 文 献}

1) Inst. of Metals: Annoted Equilibrium Diagram Series, 4 (1944)

2) J.S. Vanick: Foundry, 79, No. 8, 98; No. 9, 108 (1951)

3) W. L. William: A.S. N.E. Journal, Aug. 453 (1957)

4) 金森, 植田, 松尾：日本金属学会誌, 24, No. 5, 268 (1960)

5) E. Hasbach: Schiff und Hafen, 1957 H. 9, 747 751

\section{アセチレン化合物の酸洗い抑制 効果 (その 2$)^{*}$ アセチレン化合物と界面活性剤との配合効果}

\section{馬場 富 雄** \\ Corrosion Inhibiting Effects of Acetylenic Compounds in Acid Media. (Part 2) Synergistic Effect of Some Surface Active Agents on the Inhibiting Effect of Acetylenic Compounds}

Tomio Baba

The synergistic effect of some surface active agents on the corrosion inhibiting effect of two acetylenic compounds (i.e. propargyl alcohol and dipropargylthioether) in acid media were studied.

In the case of propargyl alcohol, it was found that the $\mathrm{N}$-containing surface active agents, such as polyoxyethylene-amide and -amine, were most effective, and that non-ionic agents, such as polyoxyethylene-alkyl or -aryl ether and -sorbitane ester, were next to them and that anionic agents, such as SDS, DBS, aerosol-OT, were almost ineffective.

In the case of dipropargyl thioether, however, all of the surface active agents, if not decomposed in the corrosion environments examined, were found to be very effective.

Polarization characteristics also confirmed the experimental results.

\section{1. 緒}

酸洗い抑制郕にはそれ自身水あるいは酸溶液に溶けて 界面活性を示するのとしからざるものとがある。前者は ポリオキシェチレン脂肪アミド，ポリオキシエチレンロ ジンフミン，フルキルフンモニウムハライド等のごとき 非イオン，㐫るいは陽イオン活性凨があげられ，後者は チオ尿素キノリン，等があげられる。界面活性を持た ない抑制剤は適当な界面活性郕と併用することで効果の 向上することが知られる。

Cardwel11) 等注キノリン，チ才尿素等による酸 溶 液 中の鉄の腐食抑制に高級アルコール硫酸エステル塩のご とき陰イオン活性刜を併用し效果の向上することを述

* 昭和 35 年 7 月 19 日学振 97 委員会月例会議で発表

** 日東理化学研究所（浦和市上木崎）

*** $\quad \begin{aligned} & \mathrm{R} \backslash \stackrel{\mathrm{OH}}{\mathrm{C}}-\mathrm{C} \equiv \mathrm{C}-\mathrm{O} \mathrm{C}\langle\mathrm{R} \\ & \mathrm{R}\end{aligned}$
ベそ理由の一つとして鉄表面上で生ずる水素の気泡 が，界面活性剂の湿潤作用で，表面にとどまり生長する ことなく，小さい泡として離脱し，ために孔食型の腐食 が抑制されると述べているが，腐食度の減少はこれのみ では説明できず，界面活性剤の他の効果をも考虑しなけ ればならぬとつけ加えている。

F. Heinrich ${ }^{2)}$ は抑制剂と界面活性剂の間では効果の 大きい抑制剂は界面活性剂により影響されないが効果 の小さいものは活性郕の添加でしばしば改善されると述 ベている。また W. Machu党) 等は希硫酸中で抑制剂 $\left(\mathrm{K}_{2} \mathrm{Cr}_{2} \mathrm{O}_{7}\right)$ と界面活性削の作用について研究し, 界面活 性郕は必ずしも抑制勃果を向上せしめず，場合によって は一旦吸着した抑制剂をその分散作用により離脱せしめ たり，また高温の場合分解した活性剮が腐食に促進的に 作用することがあると報告している。

アセチレン化合物はある種の䩶造***のものを除いて 